Jurnal Pendidikan Dasar PerKhasa

Volume 4, Nomor 2, Oktober 2018

\title{
PENGARUH KEPEMIMPINAN GURU DAN KETERAMPILAN MANAJEMEN KELAS TERHADAP PERILAKU BELAJAR SISWA KELAS IV
}

\author{
Reka Rahayu, Ratnawati Susanto \\ Pendidikan Guru Sekolah Dasar, FKIP Universitas Esa Uggul \\ Jalan Arjuna Utara No. 9, Jakarta Barat, Indonesia \\ email: rekarahayu96@gmail.com,ratnawati@esaungul.ac.id
}

\begin{abstract}
The purpose of this study was to determine whether there was an influence of teacher leadership and classroom management skills on the learning behavior of grade IV students. This research is a quantitative research using survey method. Determination of the number of samples was determined using the Slovin formula and obtained a sample of 30 respondents. Data collection techniques in this study used questionnaires. The results of testing the first hypothesis with a partial test ( $\mathrm{t}$ test) obtained $\mathrm{t}$ count $=5.108>\mathrm{t}$ table $=$ 2.052 with a significance of $0.000<0.05$ means reject $\mathrm{Ho}$ and accept $\mathrm{H} 1$. Based on these data, it means that teacher leadership variables have a positive and significant effect on learning behavior variables. The results of testing the second hypothesis with a partial test ( $\mathrm{t}$ test) obtained t count $=5.114>\mathrm{t}$ table $=2.052$ with a significance of $0.000<0.05$ means reject $\mathrm{Ho}$ and accept $\mathrm{H} 1$. Based on these data means the class management variables positively and significantly influence the learning behavior variables. The results of testing the third hypothesis with simultaneous test $(F$ test) obtained Fcount $=71.873>$ Ftable $=$ 3.35 with a significance of $0.000<0.05$ means reject Ho and accept $\mathrm{H} 1$. Based on these data means the variables of teacher leadership and classroom management simultaneously have a positive and significant effect on learning behavior.
\end{abstract}

Keywords: Teacher Laedership, Management Classroom, Learning Behavior

\begin{abstract}
Abstrak:Tujuan penelitian ini adalah untuk mengetahui apakah terdapat pengaruh kepemimpinan guru dan keterampilan manajemen kelas terhadap perilaku belajar siswa kelas IV. Penelitian ini merupakan penelitian kuantitatif dengan menggunakan metode survey.Penentuan jumlah sampel ditentukan menggunakan rumus Slovin dan diperoleh sampel sebesar 30 responden.Teknik pengumpulan data pada penelitian ini menggunakan angket. Hasil pengujian hipotesis pertama dengan uji parsial (uji t) diperoleh thitung $=5,108>$ ttabel $=2,052$ dengan signifikansi 0,000 $<0,05$ berarti tolak Ho dan terima H1. Berdasarkan data tersebut, berarti variabel kepemimpinan guru berpengaruh secara positif dan signifikan terhadap variabel perilaku belajar. Hasil pengujian hipotesis kedua dengan uji parsial (uji t) diperoleh thitung $=5,114>$ ttabel $=$ 2,052 dengan signifikansi $0,000<0,05$ berarti tolak Ho dan terima H1. Berdasarkan data tersebut berarti variabel manajemen kelas berpenaruh secara positif dan signifikan terhadap variabel perilaku belajar. Hasil pengujian hipotesis ketiga dengan uji simultan (uji F) diperoleh Fhitung $=71,873>$ Ftabel $=3,35$ dengan signifikansi $0,000<0,05$ berarti tolak Ho dan terima $\mathrm{H} 1$. Berdasarkan data tersebut berarti variabel kepemimpinan guru dan manajemen kelas secara simultan berpengaruh positif dan signifikan terhadap perilaku belajar.
\end{abstract}

Kata Kunci: Kepemimpinan Guru, Manajemen kelas, Perilaku Belajar 


\section{Pendahuluan}

Undang-Undang RI No. 20 Tahun 2003 tentang Sistem Pendidikan Nasional (Sisdiknas) menyatakan bahwa "pendidikan merupakan usaha sadar yang dilakukan untuk mengembangkan potensi peserta didik agar menjadi manusia yang beriman kepada Tuhan Yang Maha Esa, berakhlak mulia, sehat, berilmu, cakap, kreatif, mandiri dan menjadi warga negara yang demokratis serta bertanggung jawab". Dari rumusan tersebut dapat dikatakan bahwa pendidikan merupakan modal awal bagi individu atau siswa untuk memperoleh pengetahuan serta mengembangakan potensi diri yang ditempuh melalui kegiatan pembelajaran.

Kegiatan pembelajaran dapat diperoleh melalui salah satu lembaga pendidikan formal yang disebut sekolah.Kegiatan pembelajaran di sekolah merupakan interaksi dua arah, yaitu interaksi antara guru dan siswa. Melalui interaksi tersebut, akan terlihat respons dan perilaku siswa dalam menerima pembelajaran. Tentu, harapan bagi setiap guru adalah siswa dapat menunjukkan respon dan perilaku belajar yang positif. Akan tetapi, tidak setiap individu dapat menunjukkan respons yang sama dan positif.

Dalam kegiatan pembelajaran harus diperhatikan faktor-faktor yang dapat mendorong siswa agar dapat menunjukkan perilaku belajar yang positif.Hal tersebut tentu menjadi tantangan bagi guru untuk meningkatkan perilaku belajar siswa menjadi lebih baik.Dalam hal ini diperlukan peran kepemimpinan guru pada pembelajaran di kelas.

Kepemimpinan guru dalam pembelajaran menjadi faktor yang mendasar, karena berperan sebagai fasilitator yang memengaruhi interaksi dalam relasi guru sebagai pemimpin dan siswa sebagai yang dipimpin.Melalui kepemimpinannya, guru menggerakkan siswa untuk berprilaku belajar yang positif dalam pencapaian tujuan pembelajaran. Menurut Kunandar (2011) kepemimpinan guru memiliki pengaruh yang besar terhadap perilaku belajar siswa melalui proses bimbingan dan keteladanan yang syarat dengan nilai-nilai positif.

Kepemimpinan guru juga terkait erat dengan keterampilan manajemen kelas. Hal tersebut dikarenakan salah satu faktor keberhasilan suatu pembelajaran merupakan hasil dari implementasi manajemen kelas yang dilakukan guru 
secara optimal.Dapat diartikan, jika guru dapat memanajemen kelas secara optimal, berarti guru telah melaksanakan fungsinya sebagai pemimpin di kelas.

Manajemen kelas merupakan keterampilan dasar yang harus dimiliki guru dalam pengkondisian belajar yang berfokus kepada perilaku belajar siswa. Keterampilan manajemen kelas yang harus dimiliki guru, yaitu (1) keterampilan bertanya, (2) keterampilan memberi penguatan, (3) keterampilan mengadakan variasi, (4) keterampilan menjelaskan, (5) keterampilan membuka dan menutup pembelajaran,

(6) keterampilan membimbing diskusi kelompok kecil, (7) keterampilan mengelola kelas, dan (8) keterampilan mengajar kelompok kecil dan perseorangan (Susanto, 2017b).

\section{Aunurrahman}

(2012:

185)

mendefinisikan perilaku belajar sebagai kebiasaan belajar siswa yang telah berlangsung lama sehingga memberikan karakteristik tertentu terhadap aktivitas belajarnya. Definisi lain menyatakan bahwa perilaku belajar merupakan kebiasaan belajar yang dilakukan individu secara berulang-ulang sehingga menjadi otomatis atau berlangsung secara spontan (Soffatunni'mah, 2017). Syah (2014: 116) menyebutkan perwujudan perilaku belajar, yaitu (1) kebiasaan belajar akibat respons belajar yang dilakukan secara berulang-ulang, (2) kegiatan yang berhubungan dengan keterampilan, (3) kegiatan pengamatan berupa menerima, menafsirkan melaui indera-indera seperti mata dan telinga, (4) berpikir asosiatif dan daya ingat, (5) berpikir rasional dan kritis, (6) sikap atau kecenderungan siswa dalam bertindak, (7) inhibisi yaitu kesanggupan siswa dalam mengondisikan tindakan yang dilakukan, (8) apresiasi, dan (9) tingkah laku afektif berupa perasaan marah, gembira, sedih dan sebagainya.

Selain itu, faktor-faktor yang memengaruhi perilaku belajar juga didukung oleh Slameto (2015: 54) yang menyatakan bahwa faktor yang memengaruhi perilaku belajar, yaitu (1) faktor internal yang meliputi, faktor jasmaniah, faktor psikologis, dan faktor kelelahan, (2) faktor eksternal yang meliputi, faktor keluarga, faktor sekolah, dan faktor masyarakat.

Berdasarkan pendapat yang telah dipaparkan, maka dapat disimpulkan bahwa perilaku belajar merupakan kebiasaan belajar siswa yang diwujudkan dalam bentuk sikap dan perilaku positif maupun negatif dengan indikator: (1) berlangsung secara berulang-ulang, (2) adanya perubahan tingkah laku, (3) 
carasiswa mengikuti pelajaran, (4) tingkah laku afektif siswa.

Kepemimpinan berasal dari dari kata "leadership".Kepemimpinan merupakan kemampuan untuk memengaruhi kelompok menuju pencapaian sasaran (Priansa, 2014: 162).Selanjutnya Chairunnisa (2016: 107) menyatakan bahwa kepemimpinan adalah suatu kegiatan atau tindakan seseorang yang mempunyai kemampuan untuk memengaruhi perilaku seseorang dengan menggunakan kekuasaan.

Pendapat lain menyatakan bahwa kepemimpinan merupakan kemampuan untuk menggerakkan, memengaruhi, memotivasi, mengajak, mengarahkan, menasehati, membimbing, menyuruh, memerintah, melararang, dan menghukum (jika perlu), serta membina dengan maksud mencapai tujuan administrasi secara efektif dan efisien (Nasution, 2016). Kepemimpinan guru merupakan suatu kemampuan dan kesiapan yang harus dimiliki oleh seorang guru untuk mempengaruhi, membimbing dan mengarahkan atau mengelolah peserta didiknya agar mereka mau berbuat sesuatu demi terapainya tujuan pembelajaran (Kasmawati, 2017).

Kepemimpinan guru adalah suatu kesiapan, kemampuan yang dimiliki oleh seorang guru dalam proses mempengaruhi, mendorong, membimbing, mengarahkan dan menggerakkan siswanya yang ada hubungannya dengan pelaksanaan dan pengembangan proses pembelajaran (Sari, Sindang; Hendro, 2017). Lebih jauh dijelaskan bahwa kepemimpinan guru merupakan tindakan seorang guru dalam menjalankan fungsi dan perannya sebagai pendidik, dengan berfokus pada pengembangan individu, baik dirinya sebagai orang dewasa yang memengaruhi melalui kegiatan mendidik dan mengajar, juga berfokus kepada siswa (Susanto, 2017).

Kepemimpinan guru di kelas memiliki ciri dan karakteristik, seperti yang dijelaskan oleh Priansa (2014: 169) yang menyebutkan ciri dan sifat guru sebagai pemimpin, yaitu (1) energik, (2) stabilitas emosi; (3) hubungan sosial, (4) motivasi pribadi, (5) keterampilan komunikasi, (6) keterampilan mengajar, (7) keterampilan sosial, dan komponen teknis.

Berdasarkan pendapat yang telah diuraikan, maka dapat disimpulkan bahwa kepemimpinan guru merupakan kemampuan guru dalam berinteraksi dengan peserta didik di dalam kelas guna tercapainya tujuan pembelajaran, yang 
ditunjukkan dengan indikator: (1)

kemampuan memengaruhi,

kemampuan menggerakkan,

kemampuan membimbing, dan (4)

kemampuan berkomunikasi.

Manajemen kelas terdiri dari dua kata, yaitu manajemen dan kelas. Manajemen merupakan rangkaian usaha untuk mencapai tujuan yang telah ditetapkan dengan memanfaatkan orang lain. Sedangkan yang dimaksud dengan kelas adalah suatu kelompok orang yang melakukan kegiatan belajar bersama sesuai dengan tujuan yang telah ditetapkan.

Manajemen kelas menurut Priansa (2014: 234), merupakan usaha sadar untuk merencanakan, mengorganisasikan, mengaktualisasikan, dan melaksanakan pengawasan terhadap program dan kegiatan yang ada di kelas sehingga proses pembelajaran dapat berlangsung secara sistematis, efektif, dan efisien. Sedangkan menurut Djabidi (2016: 39), manajemen kelas merupakan kegiatan yang dilakukan guru secara sengaja yang meliputi kegiatan merencanakan, mengorganisasikan, mengaktualisasikan, dan pengawasan terhadap kegiatan pembelajaran sehingga terciptanya kondisi pembelajaran yang optimal.
Pendapat lainnya mengemukakan bahwa manajemen kelas merupakan keterampilan dasar yang harus dimiliki guru untuk memahami, mendiagnosa, dan melakukan tindakan memperbaiki aspek-aspek yang menjadi pendorong dan penghambat kegiatan pembelajaran (Susanto, 2017). Menurut Widiasworo (2018: 13), manajemen kelas merupakan upaya yang dilakukan oleh guru, meliputi perencanaan, pengaturan, dan pengoptimalan sumber belajar, serta sarana yang mendukung kegiatan pembelajaran. Pengelolaan kelas adalah kegiatan yang dilakukan guru yang ditunjukan untuk menciptakan kondisi kelas yang memungkinkan berlangsungnya proses pembelajaran yang optimal (Azizah, Ika Nurdiana; Estiastusi, 2017).

Keterampilan manajemen kelas mencakup antara lain: (1) keterampilan bertanya, (2) keterampilan memberi penguatan, (3) keterampilan mengadakan variasi, (4) keterampilan menjelaskan, (5) keterampilan membuka dan menutup pembelajaran, (6) keterampilan membimbing kelompok kecil, keterampilan mengelola kelas, dan (8) keterampilan mengajar kelompok kecil dan perseorangan (Susanto, 2017). 
Jurnal Pendidikan Dasar PerKhasa, Volume 4, Nomor 2, Oktober 2018

Keterampilan manajemen kelas sangat dibutuhkan, sebab terdapat tujuan yang berfokus kepada kebutuhan siswa. Adapun tujuan manajemen kelas yaitu, mendorong siswa dalam mengembangkan perilaku belajar yang sesuai dengan tujuan pembelajaran, membantu siswa dalam meningkatkan perilaku belajar yang positif guna tercapainya pembelajaran yang efektif dan efisien, mengendalikan siswa dan menciptakan kondisi pembelajaran yang kondusif, dan membantu terjalinnya interaksi yang baik antara guru dengan siswa maupun antara siswa dengan siswa, sehingga dapat tercapainya tujuan pembelajaran (Kadir, 2014).

Berdasarkan pendapat yang telah diuraikan, maka dapat disimpulkan bahwa manajemen kelas merupakan keterampilan guru yang dilakukan secara sadar guna menciptakan kondisi pembelajaran yang efektif dengan indikator: (1) keterampilan merencanakan pembelajaran, (2) keterampilan melaksanakan pembelajaran, keterampilan mengelola kelas, keterampilan mengevaluasi pembelajaran.

\section{Metode}

Metode yang digunakan dalam penelitian ini adalah metode survey.Dalam metode survey, informasi dikumpulkan dari responden dengan menggunakan kuesioner.yang digunakan untuk menemukan pengaruh kepemimpinan guru dan keterampilan manajemen kelas terhadap perilaku belajar siswa. Penelitian ini terdiri dari tiga variabel, yaitu dua variabel bebas (independent variable) dan satu variabel terikat

(dependent variable).Kepemimpinan guru sebagai variabel bebas (X1) dan keterampilan manajemen kelas sebagai variabel bebas (X2) terhadap perilaku belajar sebagai variabel terikat (Y).Pengaruh antara variabel bebas terhadap variabel terikat ditunjukkan dalam bentuk model konstelasi sebagai berikut.

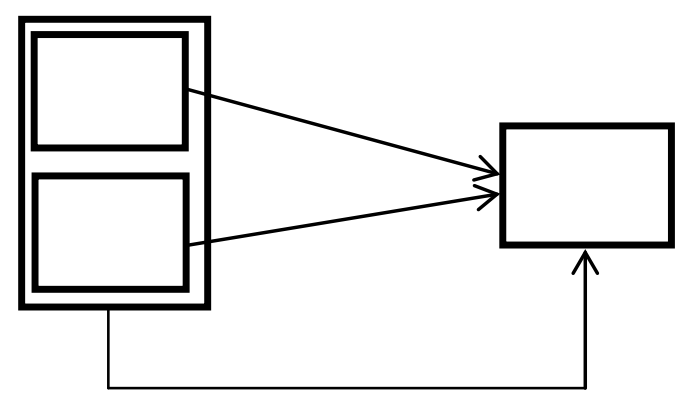

Gambar 1. Model Konstelasi 
Populasi dalam penelitian ini adalah siswa kelas IV A SDN Duri Kepa 05 Pagi yang berjumlah 32 orang. Populasi terjangkau pada penelitian ini berjumlah32dengan menggunakan Rumus Slovin dan taraf kesalahan 5\%akan diperoleh ukuran sampel sejumlah 30 siswa.

Instrumen yang digunakan dalam penelitian ini berupa kuesioner atau angket. Berdasarkan variabel yang ada maka terdapat tiga instrumen, yaitu Kepemimpinan Guru $\left(\mathrm{X}_{1}\right)$, Keterampilan Manajemen Kelas $\left(X_{2}\right)$, dan Perilaku Belajar (Y).Angket yang digunakan dalam instrumen penelitiandisusun dengan menggunakanskala Skala Likert empat options, yaitu Sangat Setuju (SS) $=4$, Setuju $(S)=3$, Tidak Setuju $(T S)=2$, dan Sangat Tidak Setuju (STS) $=1$.

Untuk menguji validitas angket, peneliti menggunakan teknik analisis Product Moment dengan taraf kepercayaan 95\%.Sedangkan untuk menguji relibilitas angket, peneliti menggunakan rumus Alpha Croncach. Untuk mengetahui apakah data berdistribusi normal, dilakukan uji normalitas model regresi menggunakan Liliefors dengan taraf signifikan 0,05. Kemudian untuk menetukan persamaan regresi, dilakukan perhitungan regresi linier berganda.

Pengujian hipotesis, dilakukan uji parsial (uji t) untuk mengetahui pengaruh masing-masing variabel bebas terhadap variabel terikat.Selanjutnya untuk mengetahui pengaruh setiap variabel bebas secara simultan terhadap variabel terikat, dilakukan uji simultan (uji F). Analisis data dilakukan menggunakan batuan program SPSS for windows release 23.

Hipotesis yang diajukan adalah:

1) $H_{0:} \beta_{1}=0$

$$
\mathrm{H}_{1}: \beta_{1} \neq 0
$$

2) $\mathrm{H}_{0:} \beta_{2}=0$

$$
\mathrm{H}_{1}: \beta_{2} \neq 0
$$

3) $\mathrm{H}_{0:} \beta_{1,2}=0$

$$
\mathrm{H}_{1}: \beta_{1,2} \neq 0
$$

\section{Hasil dan Pembahasan}

Adapun hasil penelitian dijabarkan sebagai berikut: 
Tabel 1. Tabel One-Sample Kolmogorov-Smirnov Test

\begin{tabular}{|ll|r|}
\hline & & \multicolumn{2}{|c|}{$\begin{array}{c}\text { Unstandardized } \\
\text { Residual }\end{array}$} \\
\hline $\mathrm{N}$ & Mean & 30 \\
Normal & .0000000 \\
Parameters & Std. Deviation & 1.46827344 \\
Most Extreme & Absolute & .077 \\
Differences & Positive & .063 \\
& Negative & -.077 \\
Test Statistic & & .077 \\
Asymp. Sig. (2-tailed) & $.200^{\mathrm{c}, \mathrm{d}}$ \\
\hline
\end{tabular}

Hasil perhitungan uji normalitas Liliefors, diperoleh nilai signifikansi sebesar $0,200>0,05$, artinya data berdistiribusi normal, maka dapat dinyatakan $\mathrm{H}_{\mathrm{o}}$ diterima yang berarti data berdistribusi normal.

Hasil perhitungan regresi linier berganda, diperoleh persamaan regresi $\hat{\mathrm{Y}}=11,079+0,305 \mathrm{X}_{1}+0,453 \mathrm{X}_{2}$. Persamaan regresi tersebut memiliki arti sebagai berikut.

a. Konstanta $=11,079$

Variabel kepemimpinan guru dan manajemen kelas jika diperoleh angka 0 , maka variabel perilaku belajar siswa sebesar 11,079.

b. Koefisien $X_{1}=0,305$

Variabel kepemimpinan guru jika mengalami kenaikan sebesar satu point, sementara variabel kepemimpinan guru tetap, maka akan menyebabkan kenaikan perilaku belajar siswa sebesar 0,305. Hal ini menunjukkan koefisien regresi $X_{1}$ berpengaruh positif terhadap $\mathrm{Y}$.

c. Koefisien $X_{2}=0,453$

Variabel manajemen kelas jika mengalami kenaikan sebesar satu point, sementara variabel kepemimpinan guru tetap, maka akan menyebabkan kenaikan perilaku belajar siswa sebesar 0,453 . Hal ini menunjukkan koefisien regresi $\mathrm{X}_{2}$ berpengaruh positif terhadap Y.

Hasil pengujian hipotesis pertama yaitu, uji parsial (uji t) untuk kepemimpinan guru $\left(\mathrm{X}_{1}\right)$ diperoleh $\mathrm{t}_{\text {hitung }}=$ $5,108>t_{\text {tabel }}=2,052$ dengan signifikansi $0,000<0,05$. Hasil ini menunjukkan thitung signifikan, sehingga $\mathrm{H}_{\mathrm{o}}$ ditolak dan terima $\mathrm{H}_{1}$ yang artinya terdapat pengaruh positif dan signifikan antara kepemimpinan guru terhadap perilaku belajar siswa. Kemudian hasil pengujian hipotesis kedua yaitu, uji parsial (uji t)untuk manajemen kelas $\left(X_{2}\right)$ diperoleh diperoleh $t_{\text {hitung }}=5,114>t_{\text {tabel }}=2,052$ dengan signifikansi $0,000<0,05$. Hasil ini menunjukkan $t_{\text {hitung }}$ signifikan sehingga $\mathrm{H}_{\mathrm{o}}$ ditolak dan terima $\mathrm{H}_{1}$ yang artinya terdapat pengaruh positif dan signifikan antara manajemen kelas terhadap perilaku belajar siswa. Hasil pengujian hipotesis ketiga yaitu uji simultan (uji F) 
diperoleh nilai $F_{\text {tabel }}$ sebesar 3,35. Pada tabel anova di atas, menunjukkan bahwa $F_{\text {hitung }}=71,873>F_{\text {tabel }}=3,35$ dengan signifikansi $0,000<0,05$. Hasil ini menunjukkan $F_{\text {hitung }}$ signifikan, sehingga $\mathrm{H}_{\mathrm{o}}$ ditolak dan terima $\mathrm{H}_{1}$. Bedasarkan hasil tersebut, maka terdapat pengaruh positif dan signifikan antara kepemimpinan guru dan manajemen kelas secara simultan terhadap perilaku belajar siswa.

\section{Simpulan dan Saran}

Berdasarkan data yang telah dianalisis, maka hasil penelitian tentang pengaruh kepemimpinan guru dan manajemen kelas terhadap perilaku belajar siswa kelas IV A di SDN Duri Kepa 05 Pagi Jakarta Barat, dapat ditarik kesimpulan sebagai berikut: (1) Hasil pengujian secara parsial, kepemimpinan guru memiliki pengaruh secara positif dan signifikan terhadap perilaku belajar siswa. (2) Hasil pengujian secara parsial, manajemen kelas memiliki pengaruh secara positif dan signifikan terhadap perilaku belajar siswa. (3) Hasil pengujian secara simultan, kepemimpinan guru dan manajemen kelas berpengaruh positif dan signifikan terhadap perilaku belajar siswa.
Berdasarkan simpulan yang telah diperoleh dari hasil penelitian ini, maka ada beberapa saran yang penulis berikan yang berhubungan dengan kepemimpinan guru, manajemen kelas, dan perilaku belajar yakni (1) Kepada guru hendaknya terus meningkatkan dan mengembangkan kepemimpinannya serta keterampilan manajemen kelas di dalam pembelajaran agar siswa menunjukkan perilaku belajar yang positif dan tercapainya tujuan pembelajaran. (2) Bagi peneliti selanjutnya, penelitian ini dapat dilakukan kembali dengan objek penelitian yang berbeda, serta penelitian ini dapat dimanfaatkan sebagai bahan rujukan dalam melakukan penelitian yang berkaitan dengan kepemimpinan guru, manajemen, dan perilaku belajar siswa.

\section{Daftar Pustaka}

Aunurrahman. 2012. Belajar dan Pembelajaran. Bandung: Alfabeta.

Azizah, Ika Nurdiana; Estiastusi, A. 2017. Keterampilan Guru dalam Pengelolaan Kelas Rendah pada Pembelajaran Tematik di SD. Joyful Learning Journal, 6(2), 1-6.

Chairunnisa, Connie. 2016. Manajemen Pendidikan dalam Multi Perspektif. Jakarta: PT Raja Grafindo Persada. 
Jurnal Pendidikan Dasar PerKhasa, Volume 4, Nomor 2, Oktober 2018

Djabidi, Faizal. 2016. Manajemen Pengelolaan Kelas. Malang: Madani.

Kadir, S. F. 2014. Keterampilan Mengelola Kelas dan Implementasinya dalam Proses Pembelajaran. Jurnal Al-Ta'dib, 7(2), 16-36.

Kasmawati. 2017. Pengaruh Kepemimpinan Guru Terhadap Motivasi Belajar Peserta Didik di SMP Negeri 5 Enrekang. Jurnal Idaarah, I, 181-190.

Kunandar. 2011. Guru Profesional Implementasi Kurikulum Tingkat Satuan Pendidikan (KTSP) dan Sukses dalam Sertifikasi Guru. Jakarta: Rajawali Pers.

Nasution, K. 2016. Kepemimpinan Guru dalam Meningkatkan Efektivitas Pembelajaran Pai. Jurnal Drul 'Ilmi, 04(01), 116-128.

Priansa, D. J. 2014. Kinerja dan Profesionalisme Guru. Bandung: Alfabeta.

Sari, Sindang; Hendro, O. 2017. Pengaruh Kreativitas, Komunikasi, dan Kepemimpinan Guru Terhadap Prestasi Belajar Siswa pada SMP Negeri di Kecamatan Ilir Timur II Palembang. Jurnal Ecoment, 2, 74-87.

Slameto. 2015. Belajar dan FaktorFaktor yang Mempengaruhi. Jakarta: PT Rineka Cipta.

Soffatunni'mah, E. dan P. T. 2017. Pengaruh Lingkungan Keluarga dan Motivasi Belajar Terhadap Perilaku Belajar SISWADIMAN 2
SEMARANG. Economic Education Analysis Journal, 6(2), 447-458.

Susanto, R. 2017a. Analisis Keterkaitan Kepemimpinan Guru di Kelas dan Pola Pendekatan Bimbingan Terhadap Pembentukan Nilai dan Karakter Anak Didik Usia Sekolah Dasar. Prosiding Inovasi PGSD, 1, 164-178. Retrieved from http://trilogi.ac.id/journal/ks/index. php/Prosiding/article/view/37/0

Susanto, R. 2017b. Keterampilan Manajemen Kelas Melalui Gerakan Sederhana Senam Otak (Brain Gym ) di SD Pelita 2 , Jakarta. Jurnal Abdimas, 3, 1-13.

Syah, Muhibbin. 2014. Psikologi Pendidikan dengan Pendekatan Baru. Bandung: PT Remaja Rosdakarya.

Widiasworo, Erwin. 2018. Cerdas Pengelolaan Kelas. Yogyakarta: DIVA Perss. 